\title{
ANALISA DAN PERANCANGAN SISTEM PENDUKUNG KEPUTUSAN SELEKSI ASISTEN PRAKTIKUM DI JURUSAN TEKNOLOGI INFORMASI FTIK USM MENGGUNAKAN METODE PROFILE MATCHING
}

(Analysis and Design Decision Support System for Assistant's Lab Activity Selection in Information Technology Department FTIK USM using profile matching method)

\author{
Titis Handayani \\ Program Studi Sistem Informasi, Jurusan Teknologi Informasi \\ Fakultas Teknologi Informasi dan Komunikasi, Universitas Semarang \\ Email: titis@usm.ac.id
}

\begin{abstract}
In the lab activities in Information Technology majors, the role of the assistant is certainly much needed by the lab instructor. Assistant has a job to provide assistance to students who participate in the lab if they have a trouble in the lab activities. In the selection of lab assistant mostly happen that the number of students applying always increasing, so the selection which is done based on theability to guide and to search becomes ineffective. Analysis and design of decision support system for assistant's selection using profile matching method is aims to help the selector for finding an assistant who has capability to guide and appropiate with the lab criteria more quickly and objectively.
\end{abstract}

Keywords: Decision Support System, Profile Matching

\section{PENDAHULUAN}

Kegiatan praktikum merupakan kegiatan yang menjadi bagian dari proses belajar mengajar dalam kurikulum di perguruan tinggi. Dalam kegiatan praktikum tersebut peran dari asisten tentu sangat dibutuhkan oleh instruktur praktikum. Asisten bertugas memberikan bimbingan terhadap mahasiswa peserta praktikum yang dalam mengikuti kegiatan praktikum mengalami kesulitan.

Pada Jurusan Teknologi Informasi Fakultas Teknologi Informasi dan Komunikasi Universitas Semarang setiap semester diadakan rekutmen asisten praktikum. Perekrutan ini dilakukan dengan tujuan untuk mencari mahasiswa yang mempunyai kemampuan membimbing dan menguasai materi praktikum yang di lamar. Namun di setiap pelaksanaan rekrutmen tersebut sering kali terjadi peningkatan jumlah pelamar dari mahasiswa, sehingga untuk seleksi dan juga penentuan mahasiswa yang mempunyai kemampuan dalam membimbing dan mengarahkan menjadi terkendala.

Kendala atau permasalahan yang sering terjadi adalah asisten praktikum yang terpilih ternyata kurang sesuai dengan kriteria yang diharapkan. Misalnya seorang asisten memiliki penguasaan materi praktikum yang cukup baik, tetapi ternyata tidak memiliki kemampuan verbal untuk dapat membimbing peserta praktikum, dan mungkin juga sebaliknya. Hal ini berkaitan dengan kriteria yang diterapkan dalam proses seleksi dan juga proses seleksi yang dilakukan masih secara manual, yaitu berdasarkan dokumen dari calon asisten. Proses yang demikian mengakibatkan proses seleksi yang lambat, apalagi jika 
jumlah mahasiswa yang mendaftar semakin banyak.

Usulan rancangan yang dibuat ini bertujuan untuk membantu tugas penyeleksi dalam menentukan asisten yang memiliki kemampuan membimbing dan sesuai dengan kriteria praktikum dengan tepat dan lebih cepat.

\section{DASAR TEORI}

\subsection{Profile matching}

Profile matching merupakan tahapan seleksi dimana profil dari calon asisten dibandingkan dengan profil asisten yang ditetapkan, sehingga dapat diketahui perbedaan (gap) dari profilnya. Semakin kecil gap yang dihasilkan maka bobot nilainya semakin besar yang berarti memiliki peluang lebih besar untuk menjadi asisten praktikum.

Profil dari asisten meliputi aspek akademik dan kompetensi. Aspek kompetensi meliputi kemampuan verbal, ketelitian, kesabaran, dan solusi. Sedangkan aspek akademik meliputi Indeks prestasi komulatif, nilai mata kuliah yang dilamar dan penguasaan materi.

\subsection{Penentuan Rangking}

Dalam penentuan peringkat (ranking) calon asisten yang diperlukan untuk satu asisten, seperti telah dijelaskan secara mendetail pada sebelumnya, bahwa terdapat aspek yang menentukan, adalah sebagai berikut :

- Aspek Kompetensi

- Aspek Akademik

Kemudian aspek-aspek ini, dibagi menjadi 2 bagian untuk proses perhitungannya dengan memilahnya ke dalam dua kelompok, yaitu :

a. Core Factor (Faktor Utama)

Core factor merupakan aspek yang lebih utama/lebih dibutuhkan dari seorang asisten yang diperkirakan dapat menghasilkan kemampuan yang tepat.

b. Secondary factor (Faktor Pendukung) Secondary factor adalah kemampuankemampuan selain aspek yang ada pada core factor.

\section{PEMBAHASAN}

3.1. Penghitungan gap antara profil calon asisten dan profil asisten.

Seperti yang telah di jelaskan sebelumnya bahwa terdapat dua aspek penilaian yaitu :

a. Aspek kompetensi meliputi kemampuan verbal, ketelitian, kesabaran, dan solusi.

b. Aspek akademik meliputi Indeks prestasi komulatif, nilai mata kuliah yang dilamar dan penguasaan materi.

Perhitungan gap berdasarkan rumus nilai profil mahasiswa dikurangi profil asisten. Pada pembahasan ini diambil contoh 5 data mahasiswa yang mengajukan lamaran asisten praktikum. Berikut adalah tabel penghitungan gap berdasarkan aspek kompetensi:

Tabel 1. Penghitungan gap berdasarkan aspek kompetensi

\begin{tabular}{|c|l|c|c|c|c|}
\hline No & \multicolumn{1}{|c|}{ NIM } & $\mathbf{1}$ & $\mathbf{2}$ & $\mathbf{3}$ & $\mathbf{4}$ \\
\hline 1 & G.211.10.0120 & 3 & 4 & 3 & 3 \\
\hline 2 & G.211.11.0085 & 5 & 3 & 4 & 3 \\
\hline 3 & G.111.10.0053 & 4 & 4 & 2 & 2 \\
\hline 4 & G.111.11.0027 & 2 & 3 & 4 & 4 \\
\hline 5 & G.211.10.0143 & 3 & 2 & 4 & 3 \\
\hline \multicolumn{2}{|c|}{ Profil Asisten } & 4 & 2 & 3 & 4 \\
\hline 1 & G.211.10.0120 & -1 & 2 & 0 & -1 \\
\hline 2 & G.211.11.0085 & 1 & 1 & 1 & -1 \\
\hline 3 & G.111.10.0053 & 0 & 2 & -1 & -2 \\
\hline 4 & G.111.11.0027 & -2 & 1 & 1 & 0 \\
\hline 5 & G.211.10.0143 & -1 & 0 & 1 & -1 \\
\hline
\end{tabular}

Tabel 2. Penghitungan gap berdasarkan aspek akademik

\begin{tabular}{|c|l|c|c|c|}
\hline No & \multicolumn{1}{|c|}{ NIM } & $\mathbf{1}$ & $\mathbf{2}$ & $\mathbf{3}$ \\
\hline 1 & G.211.10.0120 & 4 & 5 & 5 \\
\hline 2 & G.211.11.0085 & 2 & 4 & 3 \\
\hline 3 & G.111.10.0053 & 5 & 5 & 3 \\
\hline 4 & G.111.11.0027 & 5 & 3 & 5 \\
\hline 5 & G.211.10.0143 & 3 & 3 & 4 \\
\hline Profil Asisten & 3 & 4 & 4 \\
\hline 1 & G.211.10.0120 & 1 & 1 & 1 \\
\hline 2 & G.211.11.0085 & -1 & 0 & -1 \\
\hline 3 & G.111.10.0053 & 2 & 1 & -1 \\
\hline 4 & G.111.11.0027 & 2 & -1 & 1 \\
\hline 5 & G.211.10.0143 & 0 & -1 & 0 \\
\hline
\end{tabular}




\subsection{Penentuan bobot nilai}

Setelah diperoleh nilai tiap gap dari masing-masing mahasiswa maka tiap-tiap profil diberi bobot nilai berdasarkan tabel bobot nilai gap. Seperti bisa dilihat pada tabel berikut.

Tabel 3. Bobot Nilai Gap

\begin{tabular}{|c|c|c|l|}
\hline No & Selisih & $\begin{array}{c}\text { Bobot } \\
\text { Nilai }\end{array}$ & \multicolumn{1}{|c|}{ Keterangan } \\
\hline 1 & 0 & 5 & $\begin{array}{l}\text { Tidak ada selisih (Kompetensi } \\
\text { sesuai dengan yang dibutuhkan) }\end{array}$ \\
\hline 2 & 1 & 4,5 & $\begin{array}{l}\text { Kompetensi individu kelebihan 1 } \\
\text { tingkat / level }\end{array}$ \\
\hline 3 & -1 & 4 & $\begin{array}{l}\text { Kompetensi individu kekurangan } \\
1 \text { tingkat / level }\end{array}$ \\
\hline 4 & 2 & 3,5 & $\begin{array}{l}\text { Kompetensi individu kelebihan 2 } \\
\text { tingkat / level }\end{array}$ \\
\hline 5 & -2 & 3 & $\begin{array}{l}\text { Kompetensi individu kekurangan } \\
\text { tingkat / level }\end{array}$ \\
\hline 6 & 3 & 2,5 & $\begin{array}{l}\text { Kompetensi individu kelebihan 3 } \\
\text { tingkat / level }\end{array}$ \\
\hline 7 & -3 & 2 & $\begin{array}{l}\text { Kompetensi individu kekurangan } \\
3 \text { tingkat / level }\end{array}$ \\
\hline 8 & 4 & 1,5 & $\begin{array}{l}\text { Kompetensi individu kelebihan 4 } \\
\text { tingkat / level }\end{array}$ \\
\hline 9 & -4 & 1 & $\begin{array}{l}\text { Kompetensi individu kekurangan } \\
\text { 4tingkat / level }\end{array}$ \\
\hline
\end{tabular}

Tabel 4. Bobot nilai aspek kompetensi yang dihasilkan berdasarkan tabel pembobotan

\begin{tabular}{|c|c|c|c|c|c|}
\hline No & NIM & Verbal & Teliti & Sabar & Solusi \\
\hline 1 & G.211.10.0120 & 4 & 3.5 & 5 & 4 \\
\hline 2 & G.211.11.0085 & 4.5 & 4.5 & 4.5 & 4 \\
\hline 3 & G.111.10.0053 & 5 & 3.5 & 4 & 3 \\
\hline 4 & G.111.11.0027 & 3 & 4.5 & 4.5 & 5 \\
\hline 5 & G.211.10.0143 & 4 & 5 & 4.5 & 4 \\
\hline
\end{tabular}

Tabel 4. Bobot nilai aspek akademik yang dihasilkan berdasarkan tabel pembobotan

\begin{tabular}{|c|c|c|c|c|}
\hline No & NIM & IPK & MK & UJIAN \\
\hline 1 & G.211.10.0120 & 4.5 & 4.5 & 4.5 \\
\hline 2 & G.211.11.0085 & 4 & 5 & 4 \\
\hline 3 & G.111.10.0053 & 3.5 & 4.5 & 4 \\
\hline 4 & G.111.11.0027 & 3.5 & 4 & 4.5 \\
\hline 5 & G.211.10.0143 & 5 & 4 & 5 \\
\hline
\end{tabular}

\subsection{Penghitungan Core Factor, Secondary Factor, dan Nilai Total}

Dari nilai bobot yang telah diketahui dari tabel sebelumnya, kemudian dihitung Core Factor dan Secondary Factor dari masingmasing aspek.

Rumus menghitung Core Factor untuk aspek Kompetensi:

$N C F=\frac{\Sigma C F(\text { verbal,solusi })}{\Sigma I C}$

Keterangan:

NCF : Nilai Rata-rata Core Factor

CF : Jumlah nilai Core Factor

IC : Jumlah item Core Factor

Rumus menghitung Secondary Factor untuk aspek Akademik:

$N S F=\frac{\Sigma S F(\text { teliti,sabar })}{\Sigma I C}$

Keterangan:

NSF : Nilai Rata-rata Secondary Factor

SF : Jumlah nilai Secondary Factor

IS : Jumlah item Secondary Factor

Setelah penghitungan nilai Core Factor dan Secondary Factor,kemudian dihitung nilai totalnya, dengan rumus:

$N=(x) \% X N C F+(x) \% X N S F$

Keterangan:

$\mathrm{N}$ : Nilai Total

NCF : Nilai Rata-rata Core Factor

CF : Jumlah nilai Core Factor

$(\mathrm{x}) \%$ : prosentase yang ditentukan

Prosentasi yang diterapkan adalah $60 \%$ untuk nilai Core Factor dan $40 \%$ untuk Secondary Factor.

Dari rumus-rumus yang digunakan tersebut diperoleh hasil seperti pada tabel berikut: 
Tabel 5. Hasil Penghitungan Core Factor, Secondary Factor, dan Nilai Total Aspek Kompetensi

\begin{tabular}{|c|c|c|c|c|c|c|c|c|}
\hline No & NIM & Verbal & Teliti & Sabar & Solusi & CF & SF & Total \\
\hline 1 & G.211.10.0120 & 4 & 3.5 & 5 & 4 & 4 & 4.25 & 4.1 \\
\hline 2 & G.211.11.0085 & 4.5 & 4.5 & 4.5 & 4 & 4.25 & 4.5 & 4.35 \\
\hline 3 & G.111.10.0053 & 5 & 3.5 & 4 & 3 & 4 & 3.75 & 3.9 \\
\hline 4 & G.111.11.0027 & 3 & 4.5 & 4.5 & 5 & 4 & 4.5 & 4.2 \\
\hline 5 & G.211.10.0143 & 4 & 5 & 4.5 & 4 & 4 & 4.75 & 4.3 \\
\hline
\end{tabular}

Rumus menghitung Core Factor untuk aspek Akademik:

$N C F=\frac{\Sigma C F(\text { nilai,ujian })}{\Sigma I C}$

Keterangan:

NCF : Nilai Rata-rata Core Factor

CF : Jumlah nilai Core Factor

IC : Jumlah item Core Factor
Untuk nilai Secondary Factor diambil dari bobot IPK maka tidak menggunakan rumus. Nilai total dihitung menggunakan rumus yang sama seperti pada aspek kompetensi, perbedaanya adalah pada prosentase yang digunakan. Prosentasi yang diterapkan adalah $70 \%$ untuk nilai Core Factor dan 30\% untuk Secondary Factor. Sehingga nilai yang dihasilkan ditampilkan pada tabel berikut:

Tabel 6. Hasil Penghitungan Core Factor, Secondary

Factor, dan Nilai Total Aspek Akademik

\begin{tabular}{|c|c|c|c|c|c|c|c|}
\hline No & NIM & IPK & MK & UJIAN & CF & SF & Total \\
\hline 1 & G.211.10.0120 & 4.5 & 4.5 & 4.5 & 4.5 & 4.5 & 4.5 \\
\hline 2 & G.211.11.0085 & 4 & 5 & 4 & 4.5 & 4 & 4.35 \\
\hline 3 & G.111.10.0053 & 3.5 & 4.5 & 4 & 4.25 & 3.5 & 4.025 \\
\hline 4 & G.111.11.0027 & 3.5 & 4 & 4.5 & 4.25 & 3.5 & 4.025 \\
\hline 5 & G.211.10.0143 & 5 & 4 & 5 & 4.5 & 5 & 4.65 \\
\hline
\end{tabular}

\subsection{Penghitungan Rangking}

Hasil akhir dari proses profile matching adalah daftar urutan nilai dari mahasiswa calon asisten yang telah mengajukan lamaran. Proses penghitungan rangking berdasarkan rumus berikut:

Ranking $=(x) \% N k+(x) \% N a$

Keterangan:

$\mathrm{Nk}=$ Nilai Total aspek kompetensi

$\mathrm{Na}=$ Nilai Total aspek akademik

$(\mathrm{x}) \%=$ Nilai prosentase yang ditetapkan

Prosentase yang ditentukan adalah $60 \%$ untuk aspek Kompetensi dan 40\% untuk aspek Akademik. Rangking yang dihasilkan ditampilkan pada tabel berikut: 
Tabel 7. Rangking Calon Asisten Praktikum

\begin{tabular}{|c|c|c|c|c|}
\hline No & NIM & $\begin{array}{c}\text { Total } \\
\text { Kompetensi }\end{array}$ & $\begin{array}{c}\text { Total } \\
\text { Akademik }\end{array}$ & Rangking \\
\hline 1 & G.211.10.0120 & 4.1 & 4.5 & 4.34 \\
\hline 2 & G.211.11.0085 & 4.35 & 4.35 & 4.35 \\
\hline 3 & G.111.10.0053 & 3.9 & 4.025 & 3.975 \\
\hline 4 & G.111.11.0027 & 4.2 & 4.025 & 4.095 \\
\hline 5 & G.211.10.0143 & 4.3 & 4.65 & 4.51 \\
\hline
\end{tabular}

\section{KESIMPULAN}

Berdasarkan analisa dan perancangan sistem yang telah dipaparkan dapat diambil kesimpulan bahwa seleksi asisten praktikum dengan menggunakan metode profile matching akan menghasilkan penilaian calon asisten dengan lebih obyektif dan sesuai antara kriteria dari calon asisten dengan kriteria yang dibutuhkan, sehingga diharapkan asisten yang terpilih adalah yang mempunyai kemampuan penguasaan materi yang baik dan juga mempunyai kemampuan untuk membimbing dan mengarahkan.

\section{DAFTAR PUSTAKA}

Saaty, T.L. 2001, Decision Making for Leaders, Fourth Edition, University of Pittsburgh, RWS Publication.

Turban, E., J. E. Aronson, dan T.Liang, 2005, Decision Support System and Intelligent System, Pearson Prentice Hall, New Jersey.

Handojo, Setiabudi, dan Yunita, 2010, Pembuatan Aplikasi Sistem Pendukung Keputusan Untuk Proses Kenaikan Jabatan Dan Perencanaan Karir Pada PT. $X$, Universitas Kristen Petra Surabaya, Jurnal Informatika. 